\begin{tabular}{cc|c}
\hline Tar. Bil. Der. & Tarım Bilimleri Dergisi & Journal of Agricultural Sciences \\
& $\begin{array}{c}\text { Dergi web sayfası: } \\
\text { www.agri.ankara.edu.tr/dergi }\end{array}$ & Journal homepage: \\
& www.agri.ankara.edu.tr/journal
\end{tabular}

\title{
Contact Toxicity of Six Plant Extracts to Different Larval Stages of Colorado Potato Beetle (Leptinotarsa decemlineata SAY (Col: Chrysomelidae))
}

\author{
Mustafa ALKAN ${ }^{\mathrm{a}}$, Ayhan GÖKÇE ${ }^{\mathrm{b}}$, Kenan KARA ${ }^{\mathrm{c}}$ \\ a Plant Protection Central Research Institute, Ankara, TURKEY

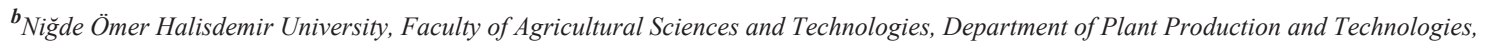 \\ Nigde, TURKEY \\ ${ }^{c}$ Gaziosmanpasa University, Faculty of Agriculture, Department of Plant Protection, Tokat, TURKEY
}

\section{ARTICLE INFO}

Research Article DOI: 10.15832/ankutbd.447616

Corresponding Author: Mustafa ALKAN, E-mail: mustafa_alkan@ziraimucadele.gov.tr, Tel: +90 (312) 3445993

Received: 04 June 2015, Received in Revised Form: 31 December 2015, Accepted: 31 December 2015

\begin{abstract}
Discovery of new eco-friendly methods for insect pest management is very important in integrated pest management program. Contact toxicity of six plant extracts i.e. Acanthus dioscoridis L. (Acanthaceae), Achillea millefolium L. (Asteraceae), Bifora radians Bieb. (Apiaceae), Heracleum platytaenium Boiss (Apiaceae), Humulus lupulus L. (Cannabaceae) and Phlomoides tuberosa (L.) Moench (Lamiaceae), were tested on the $1^{\text {st }}$ to $4^{\text {th }}$ instar larvae of Colorado potato beetle (Leptinotarsa decemlineata Say. (Coleoptera: Chrysomelidae)). The H. platytaenium and $H$. lupulus extracts were the most effective among the tested extracts, so dose-response bioassay was carried out only with $H$. lupulus and $H$. platytaenium against larval stages of Colorado potato beetle. The H. platytaenium extract was the most effective extract with calculated $\mathrm{LD}_{50}$ values $0.126,0.204,0.206$ and $0.458 \mu \mathrm{L}_{\text {insect }}{ }^{-1}, \mathrm{LD}_{90}$ values were calculated as $0.345,0.342,0.402,0.566 \mu \mathrm{L}$ insect ${ }^{-1}$ for $1^{\text {st }}, 2^{\text {nd }}, 3^{\text {rd }}$ and $4^{\text {th }}$ instars larvae respectively. These results indicate that $H$. platytaenium and $H$. lupulus extracts have great potentials as insecticides in the management of larvae of $L$. decemlineata.

Keywords: Colorado potato beetle; Plant extracts; Heracleum platytaenium; Humulus lupulus; Contact toxicity
\end{abstract}

\section{Altı Bitki Ekstraktının Patates Böceğinin (Leptinotarsa decemlineata SAY (Col: Chrysomelidae)) Farklı Dönemlerdeki Larvaları Üzerine Kontakt Etkileri}

ESER BİLGÍSİ

Araştırma Makalesi

Sorumlu Yazar: Mustafa ALKAN, E-posta: mustafa_alkan@ziraimucadele.gov.tr, Tel: +90 (312) 3445993

Geliş Tarihi: 04 Haziran 2015, Düzeltmelerin Gelişi: 31 Aralık 2015, Kabul: 31 Aralık 2015 


\section{ÖZET}

Zararlı böcekler ile mücadelede yeni çevre dostu metodların keşfi entegre zararlı yönetiminde çok önemlidir. Farklı familyalara ait altı bitki ekstraktının (Acanthus dioscoridis L. (Acanthaceae), Achillea millefolium L. (Asteraceae), Bifora radians Bieb. (Apiaceae), Heracleum platytaenium Boiss (Apiaceae), Humulus lupulus L. (Cannabaceae) and Phlomoides tuberosa (L.) Moench (Lamiaceae)) kontakt toksisiteleri patates böceğinin (Leptinotarsa decemlineata (Coleoptera:Chysomelidae)) 1-4 dönem larvalarına karşı laboratuvar koşullarında test edilmiştir. H. platytaenium ve H. lupulus ekstraktları test edilen ekstraktlar arasında tüm larval dönemler için en yüksek toksik etkiye sahip olmuştur. Çalışmanın ikinci kısmında, H. lupulus ve H. platytaenium ekstraktların ile Patates böceğinin farklı larva dönemlerinde doz-etki ile denemeleri yürütülmüştür. $H$. platytaenium ekstraktı en yüksek toksik etkiye sahip olmuş ve bu bitki ekstraktı için $\mathrm{LD}_{50}$ değerleri birinci, ikinci, üçüncü ve dördüncü dönem larvalar için sırasıyla 0.126, 0.204, 0.206 ve $0.458 \mu \mathrm{L}_{\text {böcek }}{ }^{-1}$ olarak, $\mathrm{LD}_{90}$ değerleri ise $0.345,0.342,0.402,0.566 \mu \mathrm{L}_{\text {böcek }}{ }^{1}$ olarak hesaplanmıştır. Bu sonuçlar $H$. platytaenium'un patates böceği ile mücadele de potansiyele sahip olduğunu göstermektedir.

Anahtar Kelimeler: Patates böceği; Bitki ekstraktı; Heracleum platytaenium; Humulus lupulus; Kontakt toksisite

(C) Ankara Üniversitesi Ziraat Fakültesi

\section{Introduction}

Colorado potato beetle (Leptinotarsa decemlineata $\mathrm{SAY})(\mathrm{CPB})$ is a polyphagous insect-pest causing damage to various Solanaceae plants including potato, tomato and eggplant (Hsiao 1978; Hare 1990). In absence of control tactics, yield loss can rise to even 100\% (Christie et al 1991). This cosmopolitan insect is spread over an area of 12 million $\mathrm{km}^{2}$ in the world including North America, Asia and Europe (Alyokhin 2009). It feeds on different sections of the host plants and is also vectors of certain viral plant diseases e.g. potato spindle tuber viroid (PTSVD) (Borror \& DeLong 1966; Kısmalı 1973; Jolivet et al 1988; Booth et al 1990).

A variety of insecticides are registered for the management of CPB. Extensive use of insecticides against this pest has led to serious problems like resistance, phytotoxicity and environmental contamination problems (Ioannidis et al 1991; Stewart et al 1997; Mota-Sanchez et al 2000). CPB has developed resistance to 54 insecticides belonging to different chemical classes with various modes of actions (Whalon et al 2013). These problems have led to exploration of different control methods like bio-pesticides including plant-based compounds against this pest. Although promising outcomes were reported with plant extracts especially acute toxicity and also behavioral effects (Hough-
Goldstein 1990; Scott et al 2003; 2004; Gökçe et al 2005; 2006; 2012), however limited numbers of commercialized natural products are available for use (Hassan \& Gökçe 2014).

In previous studies, $H$. lupulus and B. radinas were tested against $\mathrm{CPB}$ using total methanol extracts (Gökçe et al 2006; 2007). However, in the current study, these plants species were treated with solvent using maceration technique. This technique allows to obtain all available secondary plant metabolites using a larger amount of solvent (Hassan \& Gökçe 2014) comparing with the previous studies. The other plant species (Acanthus dioscoridis, Achillea millefolium, Heracleum platytaenium and Phlomoides tuberosa) used in this study have not been not tested against CPB yet. The objectives of the current study were to evaluate the contact toxicities of six different plant extracts on various larval stages of $\mathrm{CPB}$ and to calculate $\mathrm{LD}_{50}$ and $\mathrm{LD}_{90}$ values for the most promising extracts.

\section{Material and Methods}

\subsection{Materials}

Plant species, extracted parts and places of collection are presented in the Table 1. As described in Gökçe et al (2005), the plants were collected in the summer or spring months of 2009. After the 
separation of leafs, stems and cones from other parts, they were placed over blotting paper and kept under room temperature $\left(25{ }^{\circ} \mathrm{C}\right)$ in dark conditions for two weeks. Subsequent to drying process, the plant materials were grounded into small pieces using a mill (M 20 IKA Universal Mill, IKA Group, Wilmington, NC, USA) and then they were put into 5 liter glass jars and protected in a dark room at $15 \pm 5^{\circ} \mathrm{C}$ until they were used.

\subsection{Preparation of plant extracts}

Plant extracts were obtained through the maceration method as described in Alkan \& Gökçe (2012). Two hundred grams of each plant species were put into a 5 liter glass jar and hexane, ethyl acetate, and methanol were separately added into the jar in an order according to their polarity range. Plant materials were firstly treated with hexane for 48 hours; and then the plant suspension was filtered through Whatman ${ }^{\mathrm{TM}}$ No 4 filter paper to obtain hexane fraction. After this process, ethyl acetate was added to the jars, and the plant materials were left again in this solvent for 48 hours at room conditions. Ethyl acetate fraction was filtered through the filter paper followed by separation from plant materials. Lastly, methanol was added to the plant materials and incubated as described above and then the filtration of the suspension was also repeated for methanol fraction. Excess solvents in the suspensions were evaporated using a rotary evaporator (RV 05 Basic 1-B, IKA ${ }^{\circ}$ werke GmbH \& Co. KG, Germany) and plant residues of $A$. dioscoridis, $H$. platytaenium and $P$. tuberosa were obtained. The H. lupulus, $B$. radians and $A$. millefolium extracts were prepared using the same technique but only methanol was used as a solvent. All plant extracts were diluted with $70 \%$ acetone solution to give the concentration of $15 \%$ plant extract/acetone $\left(\mathrm{w} \mathrm{v}^{-1}\right)$. Plant extracts prepared were transferred to glass tubes and then stored at $4{ }^{\circ} \mathrm{C}$ in the refrigerator.

\subsection{Rearing of potato beetles}

Larvae of CPB were reared at Gaziosmanpasa University, Faculty of Agriculture, Plant Protection Department. CPB colony was continuously reared on potato plants (Solanum tuberosum L. cultivar Granola) which were planted at Gaziosmanpasa University Research Station in Tasliciftlik, Tokat, Turkey. The field was designated for the organic potato production and there was no pesticide application for 3 years prior to the initiation of this project and no pesticide was applied during the study. Granola cultivar was planted in a $0.2 \mathrm{ha}$ potato field. When the potato plants reached to 3 to 5 leaves stage adults of test pest were released into the field and all required stages for the studies were collected from the field.

\subsection{Single dose contact toxicity screening tests}

Single dose contact toxicity of plant extracts were separately tested on $1^{\text {st }}, 2^{\text {nd }}, 3^{\text {rd }}$, and $4^{\text {th }}$ instars larvae of CPB. Identification of larval stage was carried out using Boiteau \& Le Blancthe (1992)' key. An extract suspension $\left(15 \% \mathrm{~W} \mathrm{~V}^{-1}\right)$ was applied at a $2 \mu \mathrm{L}$ insect $^{-1}$ ratio to the dorsal of larva using a micro-syringe $25 \mu \mathrm{L}$ microsyringe connected to a microapplicator (Hamilton ${ }^{\circledR}$ Company, Reno, NV). Ten larvae were treated in each replication. After the treatment, 10 larvae were transferred into a $90 \mathrm{~mm}$ in diameter glass petri dish in which potato leaflets

Table 1- Plant species and their parts used in the study

Çizelge 1-Çalışmada kullanılan bitkiler ve kısımları

\begin{tabular}{llll}
\hline Botanical name & Family & Part used & Place collected \\
\hline Humulus lupulus & Cannabaceae & Cone & Tokat \\
Heracleum platytaenium & Apiaceae & Leaf, stem & Trabzon \\
Achillea millefolium & Asteraceae & Leaf, stem, flower & Tokat \\
Acanthus dioscoridis & Acanthaceae & Leaf, stem, flower & Erzincan \\
Phlomoides tuberosa & Lamiaceae & Leaf, stem, flower & Erzincan \\
Bifora radians & Apiaceae & Leaf, stem & Tokat \\
\hline
\end{tabular}

Tarım Bilimleri Dergisi - Journal of Agricultural Sciences 
were provided. In the control group, the larvae were treated with $70 \%$ acetone at $2 \mu \mathrm{L}_{\text {insect }}{ }^{-1}$ dose. An insecticide with spinosad active ingredient was used as a positive control, which was applied at $2 \mu \mathrm{L}$ insect $^{-1}$ dose as described above. Spinosad (Laser ${ }^{\mathrm{TM}}$, Dow Agro Sciences ${ }^{\circledR}$ ) was prepared with water at recommended dose for larvae $\left(0.1 \mathrm{~mL} \mathrm{~L}^{-1}\right)$. After the application, the larvae were incubated at $25 \pm 2{ }^{\circ} \mathrm{C}, 60 \pm 5 \%$ relative humidity $(\mathrm{RH})$ and a $16: 8$ (Light: Dark) photo period. Mortality of larvae was recorded after 24 hours after treatment (HAT). Bioassays were set up in the randomized complete block design. Experiment was repeated on three different days (blocks) and in each replication all treatment contained three subset groups.

\subsection{Dose-response bio-assay}

Based on the single-dose screening test results, dose-response bioassays were carried out with $H$. platytaenium and $H$. lupulus extracts that showed high contact toxicity to CPB larvae. These plant extracts were tested against various stages on potato beetle larvae $\left(1^{\text {st }}, 2^{\text {nd }}, 3^{\text {rd }}\right.$ and $4^{\text {th }}$ instars larvae $)$ in 6 different doses. The doses ranging from 10 to $200 \mathrm{~g}$ $\mathrm{L}^{-1}\left(10,25,50,75,100\right.$ and $150 \mathrm{~g} \mathrm{~L}^{-1}$ for the $1^{\text {st }}, 2^{\text {nd }}$ and $3^{\text {rd }}$ instar larvae, 50, 75, 100, 150, 175 and $200 \mathrm{~g}$ $\mathrm{L}^{-1}$ for the $4^{\text {th }}$ instars larvae) for $H$. lupulus and from 5 to $250 \mathrm{~g} \mathrm{~L}^{-1}\left(5,10,25,50,100\right.$ and $150 \mathrm{~g} \mathrm{~L}^{-1}$ for the $1^{\text {st }}$ instar lavae, $25,50,75,100,125$ and $150 \mathrm{~g} \mathrm{~L}^{-1}$ for the $2^{\text {nd }}$ and $3^{\text {rd }}$ instar larvae, $125,150,175,200$, 225 and $250 \mathrm{~g} \mathrm{~L}^{-1}$ for the $4^{\text {th }}$ instars larvae) for $H$. platytaenium were prepared with $70 \%$ acetone and applied to the larvae at $2 \mu \mathrm{L}$ insect ${ }^{-1}$ dose as stated above. In the control group, the larvae were treated with $70 \%$ acetone at $2 \mu \mathrm{L}_{\text {insect }}{ }^{-1}$ dose. Randomized complete block experimental design was used in this study and each block comprised all tested doses and control. Whole treatments were repeated three times. Each trial consisted of 7 treatments i.e. six doses and control group that contained three subset groups.

\subsection{Statistical analysis}

Single-dose contact toxicity screening test results were firstly converted into percent mortality and then were subjected to arcsine transformation. Variance analysis was carried out with transformed data, and additionally, the differences among treatments were analyzed by means of Tukey multiple comparison test $(\mathrm{P}<0.05)$. All statistical analyses were conducted with MINITAB $^{\circledR}$ Release 16 package program. Dose-response bioassay results were analyzed using Polo-PC probit package program (LeOra 2002), and confidence intervals were determined with $\mathrm{LD}_{50}$ and $\mathrm{LD}_{90}$ values.

\section{Results and Discussion}

\subsection{Single dose contact toxicity screening tests}

All tested plant extracts caused some contact toxicity to larvae of $L$. decemlineata, ranging from $1.5 \%$ to $100 \%$. Among the tested plant extracts, H. lupulus showed the greatest contact toxicity to $1^{\text {st }}$ instar larvae with $97.8 \%$ mortality 24 HAT. Heracleum platytaenium was the second most effective extract with $94.0 \%$ mortality rate. Mortality rates significantly between the treatments $(\mathrm{F}=86.87$; $\mathrm{df}=7,16 ; \mathrm{P}<0.05)$. Unlike $1^{\text {st }}$ instar larvae in $2^{\text {nd }}$ instar larvae, the greatest mortality was observed when treated with $H$. platytaenium followed by $H$. lupulus. After 24 hours, mortality rate was $100 \%$ in case of $H$. platytaenium extract followed by $89.8 \%$ mortality recorded in case of $H$. lupulus extract (Table 2).

Insecticidal activities of the plants belonging to Heracleum genus against important insect pest species were previously reported by other researchers. Metspalu et al (2001) tested Heracleum sosnowskyi and A. millefolium against different stages of $L$. decemlineata larvae under laboratory conditions. They reported that the greatest contact toxicity was seen in $H$. sosnowskyi extract with $80 \%$ mortality. However their findings were not comparable to our studies possibly due to variation in way of extraction of plant extracts and polarity of solvents used for extractions (Ghosh et al 2012).

Chemical analysis of plants belonging to $H$. platytaenium genus showed that the leaves contained intensive secondary metabolite compounds such as octyl acetate, octyl butyrate, (z)-4-octenyl 
Table 2- Contact toxicity of the plant extracts $\left(15 \% \mathrm{w} \mathrm{v}^{-1}\right)$ on various development stages of Leptinotarsa decemlineata larvae after 24 hours

Çizelge 2- Bitki ekstraktlarının $\left(\% 15 w v^{-1}\right)$ Leptinotarsa decemlineata'nın farklı gelişme dönemleri üzerine 24 saat sonundaki kontakt toksisiteleri

\begin{tabular}{lllll}
\hline & \multicolumn{4}{c}{$\%$ Mortality \pm SD* } \\
\cline { 2 - 5 } Treatment & 1. instar & 2. instar & 3. instar & 4. instar \\
\hline Control & $0.00 \pm 0.00 \mathrm{~b}^{1}$ & $0.00 \pm 0.00 \mathrm{c}$ & $0.00 \pm 0.00 \mathrm{c}$ & $0.00 \pm 0.00 \mathrm{c}$ \\
Acanthus dioscoridis & $1.49 \pm 1.12 \mathrm{~b}$ & $1.49 \pm 1.12 \mathrm{c}$ & $0.00 \pm 0.00 \mathrm{c}$ & $1.49 \pm 1.12 \mathrm{c}$ \\
Achillea millefolium & $2.18 \pm 1.79 \mathrm{~b}$ & $4.32 \pm 0.20 \mathrm{c}$ & $1.49 \pm 1.12 \mathrm{c}$ & $0.00 \pm 0.00 \mathrm{c}$ \\
Bifora radians & $1.49 \pm 1.12 \mathrm{~b}$ & $1.49 \pm 1.12 \mathrm{c}$ & $0.00 \pm 0.00 \mathrm{c}$ & $0.00 \pm 0.00 \mathrm{c}$ \\
Heracleum platytaenium & $94.00 \pm 4.76 \mathrm{a}$ & $100.00 \pm 0.00 \mathrm{a}$ & $100.00 \pm 0.00 \mathrm{a}$ & $3.33 \pm 0.00 \mathrm{c}$ \\
Humulus lupulus & $97.82 \pm 1.79 \mathrm{a}$ & $89.74 \pm 1.57 \mathrm{~b}$ & $95.68 \pm 0.20 \mathrm{~b}$ & $48.90 \pm 0.93 \mathrm{~b}$ \\
Phlomoides tuberosa & $1.49 \pm 1.12 \mathrm{~b}$ & $1.49 \pm 1.12 \mathrm{c}$ & $1.49 \pm 1.12 \mathrm{c}$ & $0.00 \pm 0.00 \mathrm{c}$ \\
Spinosad & $99.63 \pm 1.12 \mathrm{a}$ & $94.82 \pm 0.63 \mathrm{ab}$ & $87.10 \pm 0.84 \mathrm{~b}$ & $90.77 \pm 1.41 \mathrm{a}$ \\
\hline
\end{tabular}

${ }^{1}$, different letters following means in the same column indicate statistical significance from each other (Anova $\mathrm{P}<0.05$, Tukey test); *, standard deviation

acetate, (z)-4-octenyl butyrate, octyl 3-methyl butyrate (=octyl isovalerate), octyl hexanoate, octyl octanoate, hexyl 2-methylbutyrate, hexyl 3-methylbutyrate (=hexyl isovalerate), decyl acetate and many others. Among these elements, octyl acetate and octyl butyrate have a major share (Iscan et al 2004) and both are very important essential oils (Carroll et al 2000) thus playing role in insectpests' management (Koul et al 2008). In H. lupulus; humulene, caryophyllene and myrcene are the major constituents which are terpenes in nature thus playing significant role in insect-pests' management (Bernotienë et al 2004; Koul et al 2008). These chemicals could play an important role in toxicity of this plant species to CPB larvae.

Contact toxicity of $H$. lupulus extract was also very high and the mortality rate of $3^{\text {rd }}$ instar larvae was treated with this extract was 95.7\% 24 HAT. Similar activity with $H$. lupulus extract on the $3^{\text {rd }}$ instar larvae was also reported by Gökçe et al (2007) who observed $91 \%$ mortality on their study.

The $4^{\text {th }}$ instar larvae are the most destructive stages of CPB and cause serious damages on green parts of the plant (Wale et al 2008). The chemical standard spinosad as expected was the most effective treatment against this larval stage. Among the plant extracts, the most effective was $H$. lupulus with $48.9 \%$ mortality 24 HAT but this rate was lower than the mortality rates seen in the first three stages. Similarly, Gökçe et al (2006) reported that the first three larval stages were more sensitive than $4^{\text {th }}$ instar larvae and adult insects. Scott et al (2003) tested plant extracts belonging to Piperaceae on CPB adults and larvae and they concluded that last stage larvae, pupae and adults were less sensitive than early stage larvae were. The results of the above studies are in accordance with our results. Varying contact toxicity effects of the plant extracts to CPB larvae could be related with physiological changes in developing larvae (Karakoç \& Gökçe 2012).

\subsection{Dose-response bioassay}

Treatment of larval stages of CPB with various concentrations of $H$. platytaenium and $H$. lupulus extracts produced different $\mathrm{LD}_{50}$ and $\mathrm{LD}_{90}$ values. For $1^{\text {st }}$ instar larvae, $0.126 \mu \mathrm{L}$ insect ${ }^{-1} \mathrm{LD}_{50}$ was calculated in case of $H$. platytaenium extract while that obtained with $H$. lupulus extract was $0.150 \mu \mathrm{L}$ insect $^{-1}$ (Table 3). There was no significant difference among the treatments $(\mathrm{P}<0.05)$. The $\mathrm{LD}_{90}$ values were 0.274 and $0.345 \mu \mathrm{L} \mathrm{insect}^{-1}$ for $H$. lupulus and $H$. platytaenium extracts, respectively. For the $2^{\text {nd }}$ instar larvae, similar results were observed among treatments i.e. $\mathrm{LD}_{50}$ values were i.e. $0.168 \mu \mathrm{L}$ insect ${ }^{-1}$ and $0.204 \mu \mathrm{L}$ insect $^{-1}$ for $H$. lupulus and $H$. platytaenium $(\mathrm{P}<0.05)$. 
Additionally, no significant difference was also observed among $\mathrm{LD}_{90}$ values of these plant extracts. In the $3^{\text {rd }}$ instar larvae, calculated $\mathrm{LD}_{50}$ was 0.206 $\mu \mathrm{L}$ insect ${ }^{-1}$ for $H$. platytaenium extract and $0.149 \mu \mathrm{L}$ insect $^{-1}$ for $H$. lupulus extracts with no significant difference among the treatments (Table 3). These results showed that $\mathrm{LD}_{50}$ and $\mathrm{LD}_{90}$ values increased according to developmental stages of larvae as expected. This could be related to morphological and physiological changes in the beetle larvae as there is a considerable size difference especially between $1^{\text {st }}$ and $3^{\text {rd }}$ instars. Therefore, more plant extract is required to produce $50 \%$ or $90 \%$ mortality in the tested larvae, which leads to bigger $\mathrm{LD}_{50}$ or $\mathrm{LD}_{90}$ values. Similarly, Gökçe et al (2006) stated that $\mathrm{LD}_{50}$ and $\mathrm{LD}_{90}$ values increased according to larval stages of CPB. Doseresponse bioassay with $H$. platytaenium extract on $4^{\text {th }}$ stage larvae showed that $\mathrm{LD}_{50}$ and $\mathrm{LD}_{90}$ values were 0.458 and $0.566 \mu \mathrm{L}_{\text {insect }}{ }^{-1}$, respectively.

Table 3- Results of dose-response bioassays of Heracleum platytaenium and Humulus lupulus extracts on various development stages of Leptinotarsa decemlineata larvae after 24 hours

Çizelge 3- Heracleum platytaenium ve Humulus lupulus ekstraktlarinin 24 saat sonunda Leptinotarsa decemlineata'nın farkl gelişim dönemleri üzerindeki doz-etki denemeleri sonuçları

\begin{tabular}{|c|c|c|c|c|}
\hline Plant & Larval term & Slope $\pm S D^{*}$ & $\begin{array}{l}L D_{50}\left(\mu L \text { insect }^{-1}\right) \\
\text { (Fudicial limit })\end{array}$ & $\begin{array}{c}L D_{90}\left(\mu L \text { insect }^{1}\right) \\
\text { (Fudicial limit) }\end{array}$ \\
\hline \multirow{4}{*}{ H. platytaenium } & $1^{\text {st }}$ instar larvae & $2.927 \pm 0.234$ & $\begin{array}{c}0.126 \\
(0.087-0.190)\end{array}$ & $\begin{array}{c}0.345 \\
(0.220-0.928)\end{array}$ \\
\hline & $2^{\text {nd }}$ instar larvae & $5.710 \pm 0.460$ & $\begin{array}{c}0.204 \\
(0.154-0.285)\end{array}$ & $\begin{array}{c}0.342 \\
(0.256-1.073)\end{array}$ \\
\hline & $3^{\text {rd }}$ instar larvae & $7.443 \pm 0.578$ & $\begin{array}{c}0.206 \\
(0.189-0.226)\end{array}$ & $\begin{array}{c}0.402 \\
(0.358-0.461)\end{array}$ \\
\hline & $4^{\text {th }}$ instar larvae & $14.034 \pm 1.733$ & $\begin{array}{c}0.458 \\
(0.438-0.485)\end{array}$ & $\begin{array}{c}0.566 \\
(0.524-0.660)\end{array}$ \\
\hline \multirow{3}{*}{ H. lupulus } & $1^{\text {st }}$ instar larvae & $4.901 \pm 0.405$ & $\begin{array}{c}0.150 \\
(0.137-0.164)\end{array}$ & $\begin{array}{c}0.274 \\
(0.242-0.324)\end{array}$ \\
\hline & $2^{\text {nd }}$ instar larvae & $4.853 \pm 0.426$ & $\begin{array}{c}0.168 \\
(0.152-0.185)\end{array}$ & $\begin{array}{c}0.308 \\
(0.267-0.378)\end{array}$ \\
\hline & $3^{\text {rd }}$ instar larvae & $2.767 \pm 0.243$ & $\begin{array}{c}0.149 \\
(0.118-0.189)\end{array}$ & $\begin{array}{c}0.433 \\
(0.311-0.776)\end{array}$ \\
\hline
\end{tabular}

*, standard deviation

\section{Conclusions}

Evaluation of the plant extracts contact toxicities against the most destructive larval stages of CPB showed that especially $H$. platytaenium and $H$. lupulus were as effective as the chemical standard, spinosad, up to $4^{\text {th }}$ instar larvae, and that the extracts obtained from those plants could be used in the control of Colorado potato beetle. This research is a core study; therefore it is considered that the study will become more significant with the help of other disciplines, which enable the purification and characterization of the active compound(s). That will definitely help further development of these plant extracts by the industry.

\section{Acknowledgements}

This study has been promoted within the scope of the Project No. TAGEM-BS-12/04-04/01-04 by the Ministry of Food, Agriculture and Livestock, General Directorate of Agricultural Research and Policy. Also Turkish Republic Prime Minister State Planning Organization with project number of 27DPT-01-07-01. The authors thank to Prof. Dr. Mark E. WHALON (Michigan State University) and Prof. 
Dr. Nezhun GÖREN for their valuable time and contribution to this study.

\section{References}

Alkan M \& Gökçe A (2012). Toxic and behavioural effects of Tanacetum abrotanifolium L. DRUCE (Asteraceae) stem and flower extracts on Sitophilus granarius and Sitophilus oryzae (Col., Curculionidae). Turkish Journal of Entomology 36(3): 377-389

Alyokhin A (2009). Colorado potato beetle management on potatoes: Current challnges and future prospects. Fruit, Vegetable and Cereal Science and Biotechnology 3: 10-19

Bernotienë G, Nivinshiene O, Butkienë R \& Mochkute D (2004). Chemical composition of essential oils of hops (Humulus lupulus L.) growing wild in Aukstaitija. Chemija 15(2): 31-36

Boiteau G \& Le Blanc J P R (1992). Colorado potato beetle LIFE STAGES. Agriculture Canada Publication 1878/E, 7 pp

Borror D J \& DeLong D M (1966). An Introduction to the Study of Insects. Holt Rinehart and Winston Inc. New York, $819 \mathrm{pp}$

Booth R G, Cox M L \& Madge R B (1990). LieGuides to Insects of Importance to Man, 3. Coleoptera. The University Pres, Cambridge, 384 pp

Carroll M J, Zangerl A R \& Berenbaum M R (2000). Brief communication. Heritability estimates for octyl acetate and octyl butyrate in the mature fruit of the wild parsnip. Journal of Heredity 91(1): 68-71

Christie R D, Sumalde A C, Schutz J T \& Gudmestad N $C$ (1991). Insect transmission of the bacterial ring rot pathogen. American Potato Journal 68: 363-372

Ghosh A, Chowdhury N \& Chandra G (2012). Plant extracts as potential mosquito larvicides. The Indian Journal of Medical Research 135(5): 581-598

Gökçe A, Stelenski L L \& Whalon M E (2005). Behavioral and electrophysiological responses of leafroller moths to selected plant extracts. Environmental Entomology 34: 1426-1432

Gökçe A, Whalon M E, Çam H, Yanar Y, Demirtaş İ \& Gören N (2006). Plant extract contact toxicities to various developmental stages of Colorado potato beetles (Coleoptera: Chrysomelidae). Annals of Applied Biology 149: 197-202

Gökçe A, Whalon M E, Çam H, Yanar Y, Demirtas I \& Goren N (2007). Contact and residual toxicities of
30 plant extracts to Colorado potato beetle larvae. Archives of Phytopathology and Plant Protection 149(2): 1-10

Gökçe A, Isaacs R \& Whalon M E (2012). Dose-response relationships for the antifeedant effects of Humulus lupulus extracts against larvae and adults of the Colorado potato beetle. Pest Management Science 68: 476-481

Hare J D (1990). Ecology and management of the Colorado potato beetle. Annual Review of Entomology 35: $81-100$

Hassan E \& Gökçe A (2014). Production and consumption of biopesticides. In: D Singh (Ed), Advances in Plant Biopesticides, Springer, New York, pp. 361-379

Hough-Goldstein J A (1990). Antifeedant effects of common herbs on the Colorado potato beetle (Coleoptera: Chrysomelidae). Enviromental Entomology 19: 234-238

Hsiao T H (1978). Host-plant adaptations among geographic populations of the Colorado potato beetle. Entomologia Experimentalis et Applicata 24: 237-247

Ioannidis P M, Grafius E \& Whalon M E (1991). Patterns of insecticide resistance to azinphosmethyl, carbofuran, and permethrin in the Colorado potato beetle (Coleoptera: Chrysomelidae). Journal of Economic Entomology 84: 1417-1423

Iscan G, Ozek T, Ozek G, Duran A \& Baser K H C (2004). Essential oils of three species of Heracleum. Anticandidal Activity. Chemistry of Natural Compounds 40(6): 544-547

Jolivet P, Petipierre E \& Hasiao T H (1988). Biology of Chrysomelidae. Series Entomologicia, 42, Kluver Academic Puplishers, 606 pp

Karakoç Ö C \& Gökçe A (2012). Bitki ekstraktlarının Spodoptera littoralis (Lepidoptera: Noctuidae)'e olan kontak toksisiteleri. Türkiye Entomoloji Dergisi 36(3): 423-431

Kısmalı Ş (1973). İzmir ili ve çevresinde kültür bitkilerinde zarar yapan Chrysomelinae ve Halticinae (Coleoptera, Chrysomelidae) alt familyalarına ait türler, tanınmaları, konukçuları, yayılışları ve kısa biyolojileri üzerinde araştırmalar. Ege Üniversitesi Ziraat Fakültesi Dergisi 10(2): 341-378

Koul O, Walia S \& Dhaliwal G S (2008). Essential oils as green pesticides: Potential and constraints. Biopesticides International 4(1): 63-84

LeOra (2002). LeOra Software, Polo-Pc: Probit and Logit Analysis, Berkeley, CA, the USA 
Metspalu L, Hiiesaar K, Jõudu J \& Kuusik A (2001). The effects of certain toxic plant extracts on the larvae of Colorado potato beetle, Leptinotarsa decemlineata (Say). Practice oriented results on the use of plant extracts and pheromones in pest control: Proceedings of the International Workshop, Tartu, Estonia, 24-25 January

Mota-Sanchez D, Whalon M E, Grafius E \& Hollingworth R (2000). Resistance of Colorado potato beetle to imidacloprid. Resistance Pest Management Newsletter 11: 31-34

Scott I M, Jensen H, Scott J G, Isman M B, Arnason J T \& Philogene B J R (2003). Botanical insecticides for controlling agricultural pests: Piperamides and the Colorado potato beetle, Leptinotarsa decemlineata (Say) (Coleoptera: Chrysomelidae). Archives of Insect Biochemistry and Physiology 54: 212-225
Scott I M, Jensen H, Nicol L, Bradbuty R, Sanches-Vindas P, Poveda L, Arnason J T \& Philogene B J R (2004). Efficacy of Piper (Piperaceae) extracts for control of common home and garden insect pests. Journal of Economic Entomology 97: 1390-1403

Stewart J G, Kennedy G G \& Sturz A V (1997). Incidence of insecticides resistance in population of Colorado potato beetle, Leptinotarsa decemlineata (Say) (Coleoptera: Chrysomelidae) on Prince Edward Island. Canadian Entomologist 129: 21-26

Wale S, Platt H W \& Cattlin N (2008). Diseases, Pests and Disorders of Potatoes: A Color Handbook. Academic Press, CA, the USA, $240 \mathrm{pp}$

Whalon M E, Mota-Sanchez D, Hollingworth R \& Duynslager L (2013). Arthropod Pesticide Resistance Database. http://www.pesticideresistance.com/ (Accessed date: 11.03.2013) 